\title{
Health promotion at Swedish pharmacies - views of the staff
}

\author{
Ingeborg BJÖRKMAN, Nina VIBERG, Linda RYDBERG, Cecilia STÅLSBY LUNDBORG. \\ Received (first version): 18-Aug-2008 Accepted: 21-Nov-2008
}

\begin{abstract}
${ }^{*}$
The role of pharmacy has changed dramatically during the last decades, which has led to new demands on pharmacy personnel.

Objective: This study aims at exploring the attitudes of Swedish pharmacy personnel on their role as public health promoters and to look at the opportunities and obstacles they identify in the efforts to widen the pharmacy remit to include a wider health approach.

Method Eight focus group discussions were conducted with a strategic sample of pharmacy personnel working in two counties in Sweden. The discussions were transcribed verbatim and analysed by qualitative inductive analysis. Results Five themes were identified, "Pharmacy activities impact on public health", "The employer, Apoteket AB", "The new role welcomed", "Obstacles in the new role", and "Need of change and support". Conclusion The concept of pharmacy personnel as public health promoters was not initially in the mindset of the participants. In the process of discussion, the impact of traditional pharmacy practice as well as new pharmacy based initiatives on public health gradually became more obvious to them. The findings show a pharmacy staff involved in a process of change. The participants have not yet landed in their new role as public health promoters and the study shows that practical as well as conceptual support is needed in order for pharmacy personnel to play a more important role in public health.
\end{abstract}

Keywords: Public Health Practice. Community Pharmacy Services. Professional Practice. Sweden.

*Ingeborg BJÖRKMAN. PhD. MScPharm. Division of International Health, IHCAR, Department of Public Health Sciences, Karolinska Institutet, Stockholm, and Department of Public Health and Caring Sciences, Health Services Research, Uppsala University, Uppsala (Sweden).

Nina VIBERG. MScPharm. Division of International Health, IHCAR, Department of Public Health Sciences, Karolinska Institutet, Stockholm (Sweden).

Linda Rydberg. MSc. Division of International Health, IHCAR, Department of Public Health Sciences, Karolinska Institutet, Stockholm (Sweden).

Cecilia STÅLSBY LUNDBORG. PhD, MScPharm.

Associate Professor, Division of International Health, IHCAR, Department of Public Health Sciences, Karolinska Institutet, Stockholm, Professor, Nordic School of Public Health, Göteborg, and Apoteket AB, Stockholm (Sweden).

\section{PROMOCIÓN DE LA SALUD EN LAS FARMACIAS SUECAS - VISIONES DEL PERSONAL}

\section{RESUMEN}

El papel de la farmacia ha cambiado dramáticamente en las pasadas décadas, lo que conlleva nuevas demandas en al personal de las farmacias.

Objetivo: Este estudio trata de explorar las actitudes del personal de las farmacias suecas sobre su papel como promotores de salud, y de ver las oportunidades y obstáculos que identifican en los esfuerzos para hacer que la farmacia tenga un mayor abordaje sanitario.

Métodos: Se realizaron 8 discusiones en grupos focales con una muestra estratégica de personal de farmacias que trabajan en dos condados en Suecia. Se transcribieron las discusiones y se analizaron mediante análisis cualitativo inductivo.

Resultados: Se identificaron 5 temas: "Impacto de las actividades de farmacia en la salud pública", "El empleador, Apoteket AB", "La aceptación del nuevo papel", "Obstáculos en el nuevo papel”, y "Necesidad de cambio y apoyo". Conclusión: El concepto del personal de farmacia como promotores de salud pública no estaba inicialmente en la mente de los participantes. En el proceso de discusión, pasaron a ser más obvios para ellos el impacto de ejercicio tradicional de la farmacia, así como las nuevas iniciativas de la farmacia en la salud pública. Los hallazgos muestran un personal de la farmacia envuelto en un proceso de cambio. Los participantes todavía no han aterrizado en su nuevo papel como promotores de salud, y el estudio muestra que se necesita apoyo práctico y conceptual para que el personal de la farmacia juegue un papel más importante en la salud pública.

Palabras clave: Ejercicio en salud pública. Servicios de farmacia comunitaria. Ejercicio profesional. Suecia.

\section{INTRODUCTION}

The role of pharmacy has changed dramatically over the past decades, and a new role, built on information and advice-giving, is developing. It has been proposed that the change towards new professional roles has often been driven by pharmaceutical professional organisations and can 
be understood as a means for pharmacists to survive as an occupation. ${ }^{1}$ In Sweden all pharmacies are owned and managed by the national monopoly company, Apoteket AB. The development of pharmacy as well as the roles of the personnel has occurred under the management of the national company and without any major input of professional organisations.

The shift towards increased focus on provision of information and advice-giving at the pharmacies has occurred in parallel with changes in the society. For instance, in Sweden, healthcare regulations which have influenced the work in pharmacies include the strengthening of the patients' rights to get information about their treatment in $1982,{ }^{2}$ and to take part in treatment decisions in 1997/99., ${ }^{3,4}$ These directives regulates the duty of the pharmacy personnel in Sweden to provide information to customers on the use of medications, ${ }^{5}$ and the transition of pharmacy personnel to healthcare providers. ${ }^{6}$ During the last ten years, the awareness of health and its dependency on personal lifestyle has increased in Sweden and in many other countries. Pharmacy has gradually responded to this and is increasingly taking on a role as health promoters. $^{7,8}$

\section{Pharmacy in Sweden}

Since 1971 all pharmacies in Sweden have been owned and managed by Apoteket $A B$, a stateowned company that has a national monopoly on the retail sale of pharmaceuticals. This monopoly is planned to be discontinued in July 2009 , and during 2008 new directives for pharmacies will be established. However, as yet Apoteket $A B$ has the exclusive rights for all retail pharmacy in Sweden, including both prescribed and non-prescribed (overthe-counter, OTC medications). In 2006, Sweden had 980 pharmacies. Totally 90 million customer visits were registered and 64 million prescriptions were dispensed. Additionally, Apoteket $A B$ runs a call centre which in 2006 handled 6 million calls. ${ }^{9}$

There are three different categories of staff members at Swedish pharmacies; pharmacists (5 years' university education), prescriptionists (3 years' university education) and technicians (earlier 3 years' upper secondary school programme but now a 1.5 year post-upper secondary programme). The monopolized organisation of the Swedish pharmacies means that the same products and information material are available at all pharmacies nationally. Further, this has also had implications for the design of pharmacy premises which are similar nationally with one section for customers with prescriptions and one section for customers without prescriptions. This latter is called the self-care section.

\section{Information and advice-giving at Swedish pharmacies}

In the self-care section customers are given advice on how to treat minor ailments or, when judged necessary, are recommended to see a healthcare professional. Mainly pharmacy technicians work in this section, but a prescriptionist or a pharmacist must be available. Customers purchasing prescribed medications are served by prescriptionists or pharmacists and are given advice primarily on how to use the medications but other related issues may also be discussed. Since 2001, identified drug-related problems can be documented in all pharmacy computers and since 2002 customers at selected pharmacies can join a special profile customer programme designed for more comprehensive advice-giving, individual documentation and follow-up. ${ }^{10}$ In August 2007, there were approximately 5,900 profile customers registered at 225 pharmacies in Sweden and the number is growing. (Personal communication)

Since 1990, Apoteket $A B$ has initiated and implemented yearly information campaigns focusing on common diseases or complaints; e.g. diabetes, cardiovascular diseases, pain and infections. Traditionally, the campaigns have included information activities directed at the general public and at pharmacy customers. Documentation shows that the activities have had an impact on general public knowledge and on customer adherence to therapy recommendations. ${ }^{11-14}$

\section{Health promotion}

The campaign called the "Year of health" in 2004, had a new approach and was different from the previous campaigns: improved health by lifestyle changes was in focus. During the campaign year new health products and information materials were presented at all pharmacies, and at selected pharmacies a new activity was established: the health points programme. ${ }^{10}$ Pharmacies that joined the health points programme arranged a special area in the pharmacy where health information material and products were displayed and where the customers could meet and discuss health issues with professionals from different healthcare services, such as nursing and physiotherapy, as well as from other health related organisations. To prepare the personnel for the campaign they were offered an education package in one of three topics: "smoking", "stress" or "diet and exercise" and they were encouraged to try to improve their health themselves by lifestyle changes. This occurred during the year before the campaign.

Parallel to the introduction of the "Year of health" a new vision of Apoteket $A B$ was launched and the message was that now the pharmacy personnel should work for better health in Sweden. The new vision applied to all work conducted at pharmacies, not only the obvious health related activities during the "Year of health" but also the traditional pharmacy activities. This indicates that the managers wanted the personnel to adopt a new way of perceiving pharmacy work and a wish to make Apoteket $A B$ to an actor in the public health sector.

'Public health' deals both with the prevention of diseases and the reduction of disability and discomfort due to disease and illness, and activities directed to improve public health is concluded in the concept 'health promotion'. 'Health promotion' is sometimes used to describe activities that promote a healthy lifestyle, but in this paper is 'health 
promotion' used in its wider meaning which includes a variety of activities, among others the promotion of a healthy lifestyle.

In conclusion, the focus of the pharmacies in Sweden has gradually shifted over the years towards including new tasks; initially information on medication use was introduced, followed by the introduction of advice-giving on minor ailments, and most recently promotion of health by lifestyle changes was added as well as the notion that all pharmacy work aims at making the customers healthier (i.e. to improve public health). The development has continuously put new demands on the pharmacy personnel in their daily work. The personnel is expected both to continue to dispense and sell medications as they are used to, and to change and adopt a new role as advisors and public health promoters. This has raised questions as to where the personnel stand with regard to these new tasks and approaches. The aim of the present study was to explore the perceptions of Swedish pharmacy personnel concerning their own role as public health promoters and what opportunities and obstacles they identify which can facilitate or complicate this new public health focus at the pharmacy. Public health promotion is here understood in a wide sense and includes various activities aiming at improving public health.

\section{METHODS}

\section{Data collection}

Data was generated through eight focus group discussions (FGD) conducted with Swedish pharmacy personnel primarily working at community pharmacies in two counties in Sweden. A strategic sample of participants was recruited to give a comprehensive picture of pharmacy personnel perceptions. Participants varied in age (from 25 to 65 yrs.), staff category, and worked at different types of pharmacies (varying in size, location, and experience of health promotion activities). A majority of the focus groups were deliberately made up of only one staff category to allow the participants to freely express their thoughts. All participants, except one, were women. Women are in a considerable majority among pharmacy staff in Sweden.

Totally 35 persons participated, four or five in each group. The discussions were held from September 2004 to May 2005. The sessions lasted from 45 minutes to 80 minutes. One FGD was held in a university conference room, and the others in a separate room at a pharmacy or a pharmacy call centre. One of the authors (NV) acted as moderator at each FGD and a research assistant (JN or AM) acted as observer. An interview guide, which allowed the moderator to ask open-ended questions and to further explore the participants' answers, was used during the FGD. The questions include: "What does public health mean to you?", "What does public health promotion mean to you?", and "How is public health promotion included in your own work today?" The concepts 'public health" and 'public health promotion' were not defined and the participants were free to associate and discuss from these questions. Follow-up questions were asked to explore topics the participants brought up.

\section{Data analysis}

All FGD were performed in Swedish and transcribed verbatim. The analysis was performed by inductive qualitative method and followed a structured process combining description and interpretation of the data. ${ }^{15,16}$ The analysis begun by reading all transcripts thoroughly to give an overall understanding of the material, and thereafter meaning units were excerpted, condensed and interpreted. The interpreted meaning units were grouped and labelled with a code. These codes were compared and themes were formed. An interactive process was used throughout the analyses moving back and forth between the whole transcripts, excerpts and created concepts. Each FGD was analyzed first separately and then by two of the authors together (IB, LR). Identified themes were established in a joint discussion between three of the authors (IB, NV, LR). An example of the analyzing process from condensed meaning units to themes is shown in Table 1.

\section{Ethical consideration}

The study protocol was examined by the ethical research committee at Karolinska Institutet, Stockholm (Registration number 03-723). All participants were informed about the purpose of the study, that their participation was voluntary, and that they could withdraw from the study at any time without explanation. All data were handled confidentially. Written informed consent was collected.

\section{RESULTS}

Five themes were identified: i) Pharmacy activities impact on public health, ii) The employer, Apoteket $A B$, iii) The new role welcomed, iv) Obstacles in the new role, and $v$ ) Need of change and support.

\section{Pharmacy activities impact on public health}

Before the FGD sessions, the participants had not thought of pharmacy work as being important for public health. At first the informants thought of advice-giving on lifestyle as the most obvious activity related to public health at the pharmacy. However, as the discussions went on and the informants reflected on the subject, the task of helping customers to use their medications in a proper way was also included, as well as giving advice on how to treat minor ailments.

"You do not really realize that you are working with public health. You have other words for it." (FGD 2)

"You could say that everything we do concerns public health. We give them advice and when needed we refer them [to the health service]." (FGD 8) 


\begin{tabular}{|c|c|c|c|}
\hline Condensed MU & Condensed MU interpreted & Code & Theme \\
\hline $\begin{array}{l}\text { Customers do not know about the } \\
\text { health points programme }\end{array}$ & $\begin{array}{l}\text { The role of Apoteket as public health } \\
\text { actor is not known }\end{array}$ & \multirow{5}{*}{$\begin{array}{l}\text { The role of Apoteket } \\
\text { as public health } \\
\text { actor is not known } \\
\text { and needs to be } \\
\text { marketed }\end{array}$} & \multirow{9}{*}{$\begin{array}{l}\text { Need of change and } \\
\text { support }\end{array}$} \\
\hline $\begin{array}{l}\text { Customers primarily do not associate } \\
\text { Apoteket with lifestyle discussions }\end{array}$ & $\begin{array}{l}\text { The role of Apoteket as public health } \\
\text { actor is not known }\end{array}$ & & \\
\hline $\begin{array}{l}\text { Better marketing of the advice-giving } \\
\text { services at pharmacies is needed. }\end{array}$ & $\begin{array}{l}\text { The role of Apoteket as public health } \\
\text { actor must become well-known }\end{array}$ & & \\
\hline $\begin{array}{l}\text { Hopefully customers will gradually } \\
\text { realise that they can get advice at the } \\
\text { pharmacy }\end{array}$ & $\begin{array}{l}\text { The role of Apoteket as public health } \\
\text { actor must become more well-known. }\end{array}$ & & \\
\hline $\begin{array}{l}\text { Many customers do not know how } \\
\text { knowledgeable pharmacy staff are }\end{array}$ & $\begin{array}{l}\text { The role of Apoteket as advice-giver is } \\
\text { not known. }\end{array}$ & & \\
\hline $\begin{array}{l}\text { The dispenser-customer meeting } \\
\text { influences how medications are used } \\
\text { and how they work. }\end{array}$ & $\begin{array}{l}\text { The communication with the } \\
\text { customers has an impact. }\end{array}$ & \multirow{4}{*}{$\begin{array}{l}\text { The communication } \\
\text { with the customer is } \\
\text { crucial when } \\
\text { dispensing } \\
\text { prescriptions, in the } \\
\text { self-care } \\
\text { department, and as } \\
\text { part of the health } \\
\text { points programme. }\end{array}$} & \\
\hline $\begin{array}{l}\text { The issue of public health comes up in } \\
\text { the meeting with the customer, } \\
\text { especially when the pharmacy is in the } \\
\text { health points programme. }\end{array}$ & $\begin{array}{l}\text { The communication with the customer } \\
\text { contributes to public health. }\end{array}$ & & \\
\hline $\begin{array}{l}\text { The communication with customers is } \\
\text { important when self-care products are } \\
\text { sold, so that they are used correctly. }\end{array}$ & $\begin{array}{l}\text { Communication is important for } \\
\text { advice-giving }\end{array}$ & & \\
\hline $\begin{array}{l}\text { Often you need to ask the customer } \\
\text { questions to be able to give the right } \\
\text { advice. }\end{array}$ & $\begin{array}{l}\text { Advice-giving requires special } \\
\text { communication skills. }\end{array}$ & & \\
\hline
\end{tabular}

\section{The employer, Apoteket AB}

The participants perceived themselves as an integral part of Apoteket $A B$ and were prepared to act according to the directives of the company; they expressed loyalty to the mission of the company, quoted its vision ("Apoteket makes Sweden healthier") to explain the aim of their work, and emphasized the advantages of the monopoly. At the same time, the participants seemed to feel distanced from the management and were critical of the company's way of managing certain activities. Furthermore, they lacked support necessary for their further development.

"This is what we are aiming at: that customers can come here and at least get some advice (...). "We make Sweden healthier" - this must be central to what we do, that the customers can feel this." (FGD 6)

"I never understood the meaning of that campaign actually. (...) I think that was a bit too much actually." [The campaign encouraged customers to ask the pharmacy staff questions about sex and relationships] (FGD 5)

\section{The new role welcomed}

The new role as health promoters was welcomed by the participants; they enjoyed working closely with the customers and increasing their cooperation with other professionals. The participants made no clear boundaries between the task to promote a healthy lifestyle and to give advice on medications or minor ailments. These tasks were different parts of their advice-giving role. Furthermore participants said that pharmacies were appropriate institutions for public health promotion, being easily accessible and frequently visited by many customers. They also perceived that many customers have confidence in the competence of pharmacy staff and that it felt natural to give information about both medications and non-pharmacological treatment.

"You want that people should feel better, and it is good that you can do something in this matter [about public health promotion]." (FGD 8)

However, not all study participants appreciated this new health approach. Some preferred to develop activities within the area where they have their basic training, i.e. with issues more closely related to medications and their use.

"I think you prefer to work with issues related to your education. That's where you can contribute to healthcare." (FGD 1)

\section{Obstacles in the new role}

In the process of change, the participants identified several areas where traditional pharmacy practice was challenged. Whereas the role as advisors on how to use medications and how to treat minor ailments was perceived as familiar and comfortable, the new task as promoters of a healthy lifestyle was unfamiliar and participants felt unsafe. It felt hard to take the initiative to discuss health and this was partly explained by the low expectations among customers of getting this kind of advice at the pharmacy. Furthermore it was said that the pharmacies today were not designed and organized for personal conversations and consultations with customers, neither in terms of the layout of the premises nor how the work was organized. Cooperation with other healthcare professionals was often connected with problems and feelings of not being accepted as members of the healthcare team. 
"But it is difficult to initiate discussions with the customer. You must get into it automatically. [All other participants agree] To discuss with every customer, this is very difficult and ...you have this ordinary information that you are used to giving, and now you should ask: do you exercise?" (FGD 4)

"But it is like this when the customer comes to the pharmacy, they do not expect that they can come here and discuss lifestyle issues. On the contrary they expect to come here to get medications or to buy a skin-lotion or whatever they are after." (FGD 7)

\section{Need of change and support}

In order to make pharmacy practice more healthpromoting, certain strategies were articulated. The participants said that new competences had to be acquired to enable communication with the customers, especially about lifestyle changes. They also expressed that it takes time to become comfortable in a new role. Organisational and structural changes were also discussed, for instance pre-booked counselling sessions. To make the role of Apoteket as public health actor known by the public, marketing activities were proposed. Some of the participants had experience of the health points programme, which was mentioned as a new approach that could both enhance the customers' expectations of advice-giving on health and facilitate cooperation with other professionals.

"This is a new role for us. Previously we worked with ill people. This is new, and it will probably take some time before we know how to manage." (FDG 3)

"This [health points programme] could be a way of working to promote health as well as working together with the health service, to work with different [professional] categories." FGD 1)

\section{DISCUSSION}

In summary, the findings show a pharmacy staff involved in a process of change. The staff described how they work, how they perceive their new professional role, and the challenges they are tackling. The analysis resulted in five themes which together reveal feelings of enthusiasm combined with expressions of insecurity and proposals for what must be done to support further development. It was obvious for the participants that the national pharmacy company, Apoteket $A B$, manage the pharmacy development and they seemed to be used to follow the managers' directions. Furthermore, the thought of pharmacy work as important for public health seemed to be new but easy for the personnel to adopt at least during this discussion. However, to establish a new approach which has impact on how the personnel perform their work is of course a longer process.

\section{What do pharmacy personnel include in public health promotion?}

It has been proposed that public health promotion as a part of pharmacy practice is not only about helping people change their lifestyle; it also includes the provision of information and services that improve public health, as well as the empowerment of people to increase control over and to improve their health. ${ }^{8}$ The pharmacy personnel in this study expressed a similar reflection during the discussions. When the pharmacy personnel thought about public health promotion they spontaneously mentioned activities aiming at helping pharmacy customers to change their lifestyle. However, when the participants were given the chance to discuss and reflect on the issue, it was easy for them to realize that other pharmacy tasks which were more familiar to them also had an impact on public health. The group discussion in itself helped the participants to realise the broader content of the concept and that their own work can be considered as related to public health. Thus, a discussion like this can be seen as a step in the role change process, and broaden the staff's perception of their work.

\section{Enthusiasm to focus on health promotion}

Apoteket $\mathrm{AB}$ is a national company and the personnel are not involved in decisions concerning major activities in the pharmacies. Our study indicated that the personnel seem to be used to follow directions given by the management. The new vision of the company (that pharmacy work contribute to better health) was present in the participants minds but had not been fully adopted. This is however not a surprise, since a vision is used for long-term organisational development and not for quick changes. Concerning the "Year of health" the personnel showed enthusiasm to widen their tasks to also include health activities not directly related to medications. They said that it felt 'natural' to discuss health issues and lifestyle changes since these are closely related to the proper use of medications. Participants also stressed that the pharmacy is an excellent institution for public health promotion, an opinion that they share with others. ${ }^{1,8,17}$ Yet, little is known about the perceptions of the general public concerning the pharmacy as a source of advice on health matters. A study from the UK suggests that the public are positive towards receiving health advice at the pharmacy but that most customers are unfamiliar with discussing health issues at the pharmacy and would not bring such matters up without encouragement. ${ }^{8}$ This view, where customers do not expect advice on health matters when visiting the pharmacy, is also reflected on by some of the participants in this study. This notion is supported by another study from our research group, showing that only $30 \%$ of pharmacy customers expected to receive information on general health issues, but as many as about $75 \%$ of them believed that activities at pharmacies could influence people's willingness to improve their health. $^{18}$ 
The participants were enthusiastic about cooperating with other healthcare professionals, and they stressed that such cooperation is necessary for successful public health promotion. However, the relationship with other health professionals was described as difficult and the perceived willingness among other health professions to cooperate left much to be desired. Obviously it has been difficult to find models for cooperation across professional borders. One way to encourage cooperation might be the establishment of health points programmes. Positive reactions have been documented among healthcare professionals who participated in health points programmes. $^{19}$

Despite the general enthusiasm among most participants about health promotion activities at the pharmacy, it must be remembered that some were not as enthusiastic about implementing the new role. This was expressed as a preference to develop services that kept the focus on medications. Other studies also present ambivalent feelings among pharmacists towards changing roles within pharmacy practice. New legislation in Iceland totally changed the conditions of pharmacy ownership and this was welcomed by some pharmacists but not by others. ${ }^{20}$ This change was primarily concerned with whom had the right to own a pharmacy, but it also presented a professional challenge and requirement of new skills. However, the transition from the traditionally more technicallyoriented paradigm to a more patient-oriented paradigm has been difficult. ${ }^{21}$ In the UK, most of the pharmacists who participated in a study were enthusiastic about extending their roles but there were also opinions expressed by pharmacists who preferred to keep on dispensing. ${ }^{1}$ In Finland, a professional programme aimed at promoting patient counselling at pharmacies was difficult to implement due to low commitment among pharmacists. ${ }^{22}$

\section{Insecurity and need for support}

In contrast to the enthusiasm, feelings of insecurity towards the new professional roles were also expressed by the study participants. A prominent feature was that the personnel felt insecure about how to initiate a discussion with customers about their lifestyle. They felt pushy and many of them waited for the customer to start the discussion. A study from Northern Ireland about minimizing abuse/misuse of OTC medications shows similar findings: the staff found it difficult to approach customers, and further communication training was proposed in order to overcome these obstacles. ${ }^{23}$ However, a survey including 42,000 Swedes demonstrated that a major proportion (91\%) appreciate it when healthcare personnel (here doctors and nurses) ask them about lifestyle issues. $^{24}$ Thus, people seem to appreciate to talk about their lifestyle with healthcare professionals, but as mentioned before, they are not used to do this at the pharmacy. 8,23

The new professional role of the pharmacy personnel has involved new tasks which have meant that new demands have been put on the staff. Many of the participants expressed disappointment regarding the support from their employer concerning the need for further education and training in these tasks. Participants also expressed that they needed support to develop and transform the image of the pharmacy in the eyes of the public. The lack of marketing activities, in order to promote the shift in focus at the pharmacies, was raised as a managerial shortcoming. The participants believed that if the public was informed of the shift, they would have different expectations when visiting the pharmacy, which would make it easier for the pharmacy personnel to raise certain issues. Participants with experience of health points programme (presented earlier) were less critical of the marketing.

Another major problem was a lack of time to practise the new role and pharmacies not being designed in a way that facilitated personal consultation with the customers. Lack of time and privacy are often mentioned as problems by pharmacy personnel. ${ }^{8,25}$

\section{Methodological considerations}

Trustworthiness is of major importance in all research. In this study we used the criteria developed by Lincoln and Guba to ensure high quality. ${ }^{26,27}$ To meet the criteria of credibility we recruited pharmacy personnel with different experience to gain a broad view of the perceptions. Furthermore the analysis was well structured and carefully performed. Quotations from the text are used to illustrate the themes. Transferability must be judged by the readers themselves and to make this possible we described how the data were collected and analyzed, and gave background information about the participants. Most participants were positive toward their new health-promoting role although a minority questioned this new direction. However, it is possible that those who participated in the focus group discussions were the most interested members of pharmacy staff and thus more positive to the health approach. A study from The Netherlands tried to recruit a representative sample of pharmacists but concluded that the participants probably consisted of 'innovators' and 'early adopters'. ${ }^{25}$ This might also be true in our study.

\section{CONCLUSIONS}

The concept of pharmacy personnel as public health promoters was not initially in the mindset of the participants. In the process of discussion, the impact of traditional pharmacy practice as well as new pharmacy based initiatives on public health gradually became more obvious to them. The findings show a pharmacy staff involved in a process of change. The participants have not yet landed in their new role as public health promoters and the study shows that practical as well as conceptual support is needed in order for pharmacy personnel to play a more important role in public health. 
ACKNOWLEDGEMENTS

We are most thankful to the pharmacy personnel who participated in the focus group discussions and shared their views. We thank Apoteket $A B$ who provided a research grant for the study. We are also grateful to Anna Mattsson, Johanna Nordmark and Monika Magnusson for their contributions.

\section{CONFLICT OF INTEREST}

None declared.

\section{References}

1. Edmunds J, Calnan MW. The reprofessionalisation of community pharmacy? An exploration of attitudes to extended roles for community pharmacists amongst pharmacists and General Practitioners in the United Kingdom. Soc Sci Med. 2001;53(7):943-955

2. Ministry of Health and Social Affairs. Health and medical care policy. Hälso- och sjukvårdslagen (in Swedish). SFS 1982:763, 2b§.

3. Swedish Commission. SOU 1997:154. Patienten har rätt. Betänkande från Kommittén om hälso- och sjukvårdens finansiering och organisation, HSU 2000 (The patient is right. Report from the Committee of Health Care Financing and Organisation, HSU 2000) (in Swedish). Available from: http://www.regeringen.se/sb/d/108/a/25107 (Accessed 21 October 2008).

4. Swedish Commission. SOU 1999:66. God vård på lika villkor? - om statens styrning av hälso- och sjukvården. Betänkande från Kommittén om hälso- och sjukvårdens finansiering och organisation, HSU 2000 - Good care on equal conditions? - about the government direction of the healthcare. Report from the Committee of Health Care Financing and Organisation, HSU 2000 (in Swedish). Available from: http://www.regeringen.se/content/1/c6/02/25/75/5be1e7e6.pdf (Accessed 21 October 2008).

5. Medical Products Agency. Code of Statues. Receptföreskrifter (in Swedish). 1984 LVFS 1990:27.

6. Ministry of Health and Social Affairs. Health and medical care policy. Hälso- och sjukvårdslagen (in Swedish). SFS 1994:953.

7. Mayer JA, Eckhardt L, Stepanski BM, Sallis JF, Elder JP, Slymen DJ, Creech L, Graf G, Palmer RC, Rosenberg C, Souvignier ST. Promoting skin cancer prevention counseling by pharmacists. Am J Public Health. 1998;7:1096-1099.

8. Anderson C. Health promotion in community pharmacy: the UK situation. Patient Educ Couns. 2000;39(2-3):285-291.

9. Apoteket AB. Årsredovisning 2006 - Yearly report 2006 (in Swedish), available at http://www.apoteket.se Accessed Aug 2007.

10. Westerlund LT, Björk HT. Pharmaceutical care in community pharmacies: practice and research in Sweden. Ann Pharmacother. 2006;40(6):1162-1169.

11. Hammarstrom B, Wessling A, Nilsson JL. Pharmaceutical care for patients with skin diseases: a campaign year at Swedish pharmacies. J Clin Pharm Ther. 1995;20(6):327-334.

12. Lisper B, Nilsson JL. The asthma year in Swedish pharmacies: a nationwide information and pharmaceutical care program for patients with asthma. Ann Pharmacother. 1996;30(5):455-460.

13. Nilsson JLG, Andersson $\AA$, Kälvemark S, Lieberman-Ram H, Ullenius B, Wendel A, Åberg Å. Surveys of drug-related therapy problems of patients using medicines for allergy, asthma and pain. Int J Pharm Pract. 2000:198-203.

14. Apoteket AB. Reumaåret 2002. Rapport temaåret 2002 - The rheumatoid year 2002 (in Swedish). Stockholm: Apoteket $A B ; 2003$

15. Malterud K. Qualitative research: standards, challenges, and guidelines. Lancet. 2001;358(9280):483-488.

16. Malterud K. Kvalitativa metoder i medicinsk forskning (Qualitative methods in medical research) (in Swedish). Lund: Studentlitteratur; 1998.

17. Lloyd-Williams $F$. The effect of an intervention programme to improve health education leaflet uptake and distribution in community pharmacies. Patient Educ Couns. 2003;49(1):27-33.

18. Larsson EC, Viberg N, Vernby Å, Nordmark J, Stålsby Lundborg C. Health information, an area for competition in Swedish pharmacies. Pharmacy Practice (Internet). 2008;6(2):74-78.

19. Nordling S. Hälsotorget i Lyckeby. Hur har det påverkat befolkningen och hälso- och sjukvårdsverksamheten? - The Health point in Lyckeby. How are the public and healthcare influenced? (in Swedish). Lund: IHE Rapport 2003:1; 2003.

20. Morgall JM, Almarsdottir AB. No struggle, no strength: how pharmacists lost their monopoly. Soc Sci Med. 1999;48(9):1247-1258

21. Almarsdottir AB, Morgall JM. Technicians or patient advocates?--still a valid question (results of focus group discussions with pharmacists). Pharm World Sci. 1999;21(3):127-131.

22. Kansanaho H, Puumalainen I, Varunki M, Ahonen R, Airaksinen M. Implementation of a professional program in Finnish community pharmacies in 2000-2002. Patient Educ Couns. 2005;57(3):272-279.

23. Wazaify M, Hughes CM, McElnay JC. The implementation of a harm minimisation model for the identification and treatment of over-the-counter drug misuse and abuse in community pharmacies in Northern Ireland. Patient Educ Couns. 2006;64(1-3):136-141.

24. Swedish Association of Local Authorities and Regions. Barometer of public opinions on healthcare (Sveriges Kommuner och Landsting. Vårdbarometern) (In Swedish) Available at http://www.vardbarometern.nu/downloads/Vardbarometern_2006.pdf Accessed 23 October 2007.

25. Pronk MC, Blom AT, Jonkers R, Van Burg A. The diffusion process of patient education in Dutch community pharmacy: an exploration. Patient Educ Couns. 2001;42(2):115-121. 
26. Lincoln Y, Guba E. Naturalistic Inquiry. Beverly Hills: Sage; 1985.

27. Hamberg K, Johansson E, Lindgren G, Westman G. Scientific rigour in qualitative research--examples from a study of women's health in family practice. Fam Pract. 1994;11(2):176-181. 